\title{
Peran Budaya Sekolah sebagai Hidden Curriculum Pembentuk Karakter Lulusan Lembaga Pendidikan Islam
}

\author{
Oleh: Binti Nasukah \\ STIT Ibnu Sina, Kepanjen, Malang \\ abin_maulani@yahoo.com
}

\begin{abstract}
The criticism addressed to Islamic Education Institutions (IEI) attribute to its incompetence to overcome the bad habit in this country such as corruption, collusion and nepotism, raise the need of IEI to realize the existence of hidden curriculum. It is side effect of education when formal curriculum to be implemented, through school culture. Hidden curriculum embedded in school culture that participate in creating student's character. Using literature studies, this article try to give undertstanding about the importance of hidden curriculum, including its existence and sources, and give recommendation for IEI's administrators to evaluate the aspects contributing to school culture and impacting the hidden curriculum. It is hoped that realizing the existence of hidden curriculum will help IEI to evaluate many posibilities that cause unexpected output of education.
\end{abstract}

Keywords: hidden curriculum, school culture, Islamic education institutions

\begin{abstract}
ABSTRAK
Kritik terhadap lembaga pendidikan Islam (LPI) atas ketidakmampuan dalam mengatasi penyakit seperti KKN dalam negeri ini, memunculkan perlunya lembaga pendidikan Islam untuk memperhatikan satu aspek penting yang tidak disadari muncul dalam penyelenggaraan kegiatan belajar mengajar di LPI, yaitu hidden curriculum (kurikulum tersembunyi). Terdapat hasil sampingan yang tidak sengaja muncul akibat diimplementasikannya kurikulum resmi, yang bersumber dari budaya sekolah yang terbangun. Budaya sekolah menjadi hidden curriculum yang turut serta membentuk karakter siswa yang dihasilkan. Untuk itu, melalui kajian literatur, artikel ini berupaya memberikan pemahaman terkait keberadaan hidden curriculum, sumber-sumber keberadaan hidden curriculum dan argumentasi pentingnya pihak penyelenggara LPI untuk menyadari, memahami dan mengevaluasi aspek-aspek pembentuk budaya
\end{abstract}




\section{Binti Nasukah}

sekolah yang menjadi sumber hidden curriculum sebuah LPI. Diharapkan dengan pemahaman akan pentingnya keberadaan hidden curriculum ini, LPI dapat mengevaluasi berbagai kemungkinan yang menjadi penyebab tidak tercapainya lulusan yang diharapkan umat.

Kata kunci: hidden curriculum, kurikulum tersembunyi, budaya sekolah, LPI

\section{A. PENDAHULUAN}

Lembaga pendidikan Islam yang muncul mulai sejak munculnya masyarakat Islam Nusantara, ${ }^{1}$ kini telah berkembang dalam jumlah besar di berbagai jenis jenjang, seperti: pondok pesantren dan sekolah diniyah; madrasah, mulai tingkat dasar hingga tingkat atas, dan tingkat pendidikan Tinggi. Sebagai sekolah yang berbasis agama, lembaga-lembaga tersebut tentu memiliki tuntutan lebih dalam output lulusan yang dihasilkan. Tidak hanya dituntut untuk melahirkan generasi yang pintar secara kognitif, memiliki pengetahuan luas bidang yang diajarkan, memiliki ketrampilan untuk bisa eksis sebagai bagian dari masyarakat, tetapi yang tidak kalah penting adalah melahirkan generasi yang berakhlaqul karimah, yaitu berperilaku baik sesuai dengan nilai-nilai keislaman. Artinya, mereka dituntut untuk menghasilkan generasi insan kamil, manusia seutuhnya yang pintar otaknya, ahli dalam bidangnya, serta baik perilakunya.

Meski lembaga-lembaga pendidikan Islam tersebut berpredikat sebagai sekolah agama, yang tujuannya mulia membentuk insan kamil, menurut Fadjar² keberadaan mereka, baik secara terpisah maupun bersama-sama, tidak serta

\footnotetext{
${ }^{1}$ Azyumardi Azra, Jaringan Ulama Timur Tengah dan Kepulauan Nusantara Abad XVII \& XVIII: Akar Pembaruan Islam Indonesia (Cet. II; Jakarta: Prenada Media, 2005), hlm. 1-6.

${ }^{2}$ A. Malik Fadjar, Visi Pembaharuan Pendidikan Islam, (Jakarta: Lembaga Pengembangan Pendidikan dan Penyusunan Naskah Indonesia, 1998), hlm. 104.
} 


\section{Peran Budaya Sekolah sebagai Hidden Curriculum Pembentuk Karakter Lulusan Lembaga Pendidikan Islam}

merta memenuhi apa yang diharapkan umatnya. Terbukti masih banyak kritik yang dialamatkan kepada lembaga pendidikan Islam, utamanya dalam pengaruhnya terhadap pembentukan budaya bangsa. Seperti salah satu kritikan yang datang dari Prof. Dr. H. Cecep Sumarna, ${ }^{3}$ yang menemukan bahwa meskipun lulusan-lulusan LPI telah banyak yang masuk ke ranah birokrasi negara, namun tidak secara otomatis mengurangi budaya birokrasi yang cenderung koruptif, kolutif dan nepotistik (KKN). Dalam kasus tertentu, alumni LPI bahkan seolah menjadi bagian penting dari penguatan budaya KKN. Kritikan ini harusnya menjadi renungan para pengelola LPI, dan mulai mengevaluasi dengan mempertanyakan apa yang kurang terperhatikan dalam pengelolaan LPI sehingga belum mampu menghasilkan lulusan yang mencerminkan nilai-nilai keislaman?

Artikel ini membahas peran salah satu faktor penting yang keberadaannya sering terabaikan dalam pengelolaan sebuah LPI, utamanya dalam pembentukan karakter dan akhlak siswa, yaitu hidden curriculum (kurikulum tersembunyi). Disebut sering terabaikan karena keberadaannya yang memang tersembunyi dan tidak disadari atau tidak sengaja dimaksudkan untuk diajarkan. Hidden curriculum ini ada bersamaan ketika kurikulum resmi sedang dijalankan. Sekolah, pada dasarnya merupakan sebuah komunitas bermasyarakat di mana siswa bersosialisasi. Mereka tidak hanya akan menerima materi-materi, pelajaran atau

\footnotetext{
${ }^{3}$ Cecep Sumarna, "Alumni Madrasah", diposting tanggal 7 September 2014, tersedia di http://cecepsumarna.com/alumni-madrasah/
} 


\section{Binti Nasukah}

mata kuliah, yang tertuang dalam kurikulum resmi, tetapi lebih dari itu, mereka juga merasakan, mendengar, dan meniru nilai-nilai, sikap, pola pikir dan perilaku yang mereka dapatkan selama mereka bersosialisasi dan hidup bermasyarakat di dalam sebuah komunitas sekolah. Hal inilah yang sering terabaikan oleh LPI.

Sebagai warisan, LPI merupakan amanat sejarah untuk dipelihara dan dikembangkan oleh umat Islam dari masa ke masa. ${ }^{4}$ Pengelolaannya membutuhkan pemahaman hidden curriculum dan keterkaitannnya dengan school culture (budaya sekolah) dalam upaya mencetak generasi insan kamil. Diharapkan dengan memahami kedua unsur ini, akan membuka wawasan pengelola LPI untuk lebih jeli melihat berbagai kemungkinan hidden curriculum yang tidak sengaja mereka ajarkan kepada siswa hingga terbentuk karakter yang berbeda dengan apa yang diharapkan dalam kurikulum resmi.

\section{B. PEMBAHASAN}

\section{Memahami Hidden Curriculum}

Pada umumnya, kurikulum didefinisikan sebagai seperangkat rencana dan pengaturan mengenai isi dan bahan pelajaran serta cara yang digunakan sebagai pedoman penyelenggaraan kegiatan belajar mengajar. ${ }^{5}$ Pengertian lama tentang kurikulum ini umumnya lebih menekankan pada isi pelajaran atau mata kuliah, dalam arti sejumlah mata pelajaran atau mata kuliah di

\footnotetext{
${ }^{4}$ Husaini Rahim, Arah Baru Pendidikan Islam di Indonesia, (Jakarta: PT. Logos Wacana Ilmu, 2001), hlm. 3

${ }^{5}$ Oemar Hamalik, 2005, Proses Belajar Mengajar, Jakarta: Bumi Aksara, hlm. 66
} 


\section{Peran Budaya Sekolah sebagai Hidden Curriculum Pembentuk Karakter Lulusan Lembaga Pendidikan Islam}

sekolah atau perguruan tinggi, yang disajikan oleh suatu lembaga pendidikan. ${ }^{6}$ Jika merujuk pada pengertian ini, maka umumnya lembaga pendidikan hanya akan berkonsentrasi pada mata pelajaran apa yang akan diajarkan, materi apa yang diajarkan, buku apa yang akan diajarkan, dan halhal lain yang sifatnya berkaitan dengan pengetahuan. Padahal, jika merujuk pada tujuan pendidikan Nasional dan bahkan tujuan pendidikan Islam, harusnya kurikulum dipandang lebih luas dari sekedar mata pelajaran, buku, atau materi.

Berdasarkan UU No. 20 Tahun 2003, pendidikan dimaksudkan untuk mewujudkan suasana belajar dan proses pembelajaran agar peserta didik secara aktif mengembangkan potensi dirinya untuk memiliki kekuatan spiritual keagamaan, pengendalian diri, kepribadian, kecerdasan, akhlak mulia, serta keterampilan yang diperlukan dirinya, masyarakat, bangsa dan negara. Maksud ini selaras dengan pengertian pendidikan Islam, yang dijelaskan Yusuf Qardlawi7 bahwa pendidikan Islam adalah sebagai proses arahan dan bimbingan untuk mewujudkan manusia seutuhnya; akal dan hatinya; rohani dan jasmaninya, akhlak dan ketrampilannya sehingga mereka siap menjalani kehidupan dengan baik di manapun dan kapan pun berdasarkan nilai-nilai Islam. Dengan demikian, pengelolaan LPI, pada dasarnya membawa amanat untuk mengarahkan tujuan pendidikan pada

\footnotetext{
${ }^{6}$ Muhaimin, 2004, Pengembangan Kurikulum Pendidikan Agama Islam, Jakarta: Raja Grafindo, hlm. 2

${ }^{7}$ Yusuf Qardlawi, Pendidikan lslam dan Madrasah Hasan al Banna, terjemah oleh Bustani A. Gani, (Jakarta : Bulan Bintang, 1980), hlm. 157
} 


\section{Binti Nasukah}

pembentukan manusia seutuhnya, atau dikenal dengan istilah insan kamil. Artinya, pendidikan harus diarahkan pada pengembangan tiga aspek, yaitu kognitif, afektif dan psikomotorik. Tidak hanya berkembang akalnya, tetapi juga harus ahli atau terampil serta memiliki akhlak atau budi pekerti yang baik, yang sejalan dengan nilai-nilai keislaman.

Untuk mencapai tujuan tersebut, sebuah lembaga pendidikan harus dapat memandang kurikulum secara lebih luas. Tidak hanya sekedar merencanakan, mengarahkan dan melaksanakan kegiatan belajar mengajar demi tersampaikannya materi-materi pelajaran, sebuah lembaga pendidikan juga harus mempersiapkan sebuah tatatan sekolah yang terencana dan terstruktur dengan baik, karena akan menjadi wadah bagi siswa-siswi untuk belajar bermasyarakat dalam sebuah komunitas yang disebut dengan sekolah. Dalam hal ini sekolah juga perlu memperhatikan hal-hal tersembunyi yang menjadi hasil sampingan dari diselenggarakkannya kegiatan belajar-mengajar, yang dikenal dengan istilah hidden curriculum.

Istilah hidden curriculum (Kurikulum tersembunyi) didefinisikan secara seragam oleh para ahli. Martin mendefinsikan hidden curriculum sebagai hasil (sampingan) dari sebuah pendidikan, di mana hasilnya dipelajari tetapi tidak secara tersurat dicantumkan sebagai tujuan, atau dapat juga dikatakan dengan istilah pengalaman belajar, yang tidak sengaja diajarkan, tetapi menjadi 


\section{Peran Budaya Sekolah sebagai Hidden Curriculum Pembentuk Karakter Lulusan Lembaga Pendidikan Islam}

pengetahuan yang dapat mempengaruhi siswa. ${ }^{8}$ Hasil ini dianggap sebagai pelajaran yang diajarkan informal, dan biasanya tidak sengaja, dalam sistem sekolah, termasuk didalamnya perilaku, perspektif, dan sikap yang diterima siswa selama mereka berinteraksi dan berada di sekolah. Tentu saja ini kontras dengan kurikulum formal, yang biasanya telah tertulis dan dirancang untuk diajarkan siswa dalam kelas-kelas di mana siswa berpartisipasi di dalamnya. Tidak berbeda, Horn ${ }^{9}$ mendefiniskan hidden curriculum dalam kategori luas mencakup segala hal terkait dengan pengetahuan, nilai, dan keyakinan yang tidak disadari atau bahkan tidak disengaja sebagai bagian dari proses pembelajaran di sekolah dan di dalam kelas. Secara singkat, Konieczka ${ }^{10}$ menjelaskan bahwa istilah hidden curriculum digunakan untuk menjelaskan sebagai nilai-nilai yang tidak sengaja terbentuk dalam rangka praktik pembelajaran di kelas atau di dalam institusi pendidikan.

Dari berbagai definisi yang dipaparkan para ahli diatas, terdapat satu unsur pokok untuk menyebut apa yang dimaksudkan dengan hidden curriculum, yaitu ketidaksengajaan. Dikatakan ketidaksengajaan karena hidden curriculum hadir secara tidak sengaja bersamaan pada saat kurikulum resmi (tertulis) dilaksanakan. Contoh, pada saat guru mengajar salah satu mata

\footnotetext{
${ }^{8}$ Jane Martin, What Should We Do with a Hidden Curriculum When We Find One? The Hidden Curriculum and Moral Education. Ed. Giroux, Henry, dan David Purpel. Berkeley, California: McCutchan Publishing Corporation, 1983. 122-139.

${ }^{9}$ Raymond A Horn, Jr. Developing a Critical Awareness of the Hidden Curriculum through Media Literacy. The Clearing House v. 76 no. 6 (July/August 2003) p. 298-300.

${ }^{10}$ Joanna Konieczka. The Hidden Curriculum: as a socialization of schooling is in process at all times, and serves to transmit messages to students about values, attitudes and principles. Advanced Research in Scientific Areas. December, 2 . (6) 2013, pp. 250-252
} 


\section{Binti Nasukah}

pelajaran di kelas, pada dasarnya secara tidak sengaja guru telah mengajarkan bagaimana cara bertutur kata dengan orang lain. Karena tidak sengaja diajarkan, maka kurikulum tersembunyi ini bisa menjadi pengetahuan yang berkonotasi negatif11, menjadi penghalang terwujudnya tujuan pendidikan. Seperti yang dimisalkan oleh Michael dan King ${ }^{12}$ bahwa kurikulum tersembunyi bisa memperkuat terjadinya ketidaksamaan sosial dengan mendidik siswa dalam berbagai persoalan dan perilaku menurut kelas dan status sosial mereka. Seorang guru bisa secara tidak sengaja bertindak lebih menganakemaskan anak pejabat atau siswa dari kalangan kaya, dibanding dengan siswa lain yang dari kelas sosial biasa. Guru mungkin tidak sengaja mengajarkan ini, tapi siswa bisa memiliki persepsi bahwa mereka dilihat berdasarkan jabatan atau kekayaan dari orang tua mereka. Dan ini bisa menjadi karakter yang melekat, bahkan ketika mereka telah keluar dari bangku sekolah.

Hal lain yang juga perlu disadari oleh para pengelola LPI adalah bahwa hidden curriculum (kurikulum tersembunyi) itu ada dan bahkan telah ada sejak di tingkat awal pendidikan anak. Para siswa belajar tentang berbagai bentuk pendapat dan ide-ide tentang lingkungan, guru, dan teman-teman sekelas mereka. Anak-anak akan belajar sesuai dengan cara yang diajarkan di sekolah. Mereka akan belajar dari apa yang diharapkan dari mereka. Siswa bisa

\footnotetext{
${ }^{11}$ Catherine Cornbleth. Beyond Hidden Curriculum? Journal of Curriculum Studies. 16.1(1984): 29-36.

${ }^{12}$ Michael Apple and Nancy King. "What Do Schools Teach?" The Hidden Curriculum and Moral Education. Ed. Giroux, Henry and David Purpel. Berkeley, California: McCutchan Publishing Corporation, 1983. 82-99.
} 


\section{Peran Budaya Sekolah sebagai Hidden Curriculum Pembentuk Karakter}

Lulusan Lembaga Pendidikan Islam

menjadi anak yang pasif, karena guru lebih suka anak yang 'anteng' daripada yang aktif. Bisa jadi anak menjadi lebih mementingkan kuantitas, karena guru lebih peduli pada hasil makalah yang lebih tebal dibandingkan isi pemikirannya. Sikap dan ide-ide ini ini tidak diajarkan secara formal, tetapi siswa menyerap dan menginternalisasi melalui pengamatan alami dan partisipasi mereka dalam lingkungan lembaga pendidikan. Hidden curriculum (kurikulum tersembunyi) ini bisa membentuk perspektif siswa dalam berbagai bidang dan persoalan: jenis kelamin, moral, kelas sosial, budaya, politik, bahasa, dan sebagainya, yang pada akhirnya dapat membentuk karakter mereka. Dengan demikian dipahami bahwa keberadaan hidden curriculum memegang peran yang sangat penting untuk ikut membentuk output lulusan.

\section{Sumber dari Keberadaan Hidden Curriculum}

Keberadaan hidden curriculum sebagai faktor yang ikut berperan serta dalam membentuk output lulusan, mengharuskan para pengelola LPI untuk menyadari, memahami dan mengevaluasi apa saja yang menjadi sumber keberadaan hidden curriculum. Utamanya dalam pembentukan akhlak siswa. Artinya, LPI harus menyadari hal-hal apa saja yang bisa ikut dirasakan, didengar, dan diinternalisasi oleh siswa. Sumber keberadaan kurikulum tersembunyi ini umumnya berasal dari hal-hal informal yang menempel saat siswa menjalani proses kegiatan belajar mengajar atau selama mereka bersosialisasi di sekolah. Hal-hal tersebut bisa jadi tidak berasal dari 


\section{Binti Nasukah}

kurikulum resmi yang direncanakan, tetapi ikut menjadi bagian saat dilaksanakannya kurikulum resmi tersebut.

Untuk mengetahui hal-hal apa saja yang menjadi sumber keberadaan hidden curriculum, maka LPI harus dipandang sebagai sebuah organisasi yang terdiri kumpulan orang yang terorganisir dalam upaya mencapai tujuan LPI. Artinya, terdapat aspek kultural di mana sekelompok orang saling berinteraksi membangun budaya organisasi dan terdapat aspek struktural di mana organisasi melaksanakan kegiatan pengorganisasian. Hal ini menunjukkan bahwa sumber keberadaan hidden curriculum bisa berasal dari kedua aspek tersebut, yaitu: struktural dan kultural.

Pertama, adalah aspek struktural, merupakan aspek yang berkaitan dengan kegiatan struktural atau kegiatan pengorganisasian sebuah lembaga pendidikan. Dalam upaya mencapai tujuan pendidikan mencetak generasi insan kamil, LPI melakukan banyak kegiatan struktural yang bertujuan menata, mengatur, mengorganisasikan berbagai sarana prasarana serta kegiatan yang sesuai dengan tujuan pendidikan. Kegiatan-kegiatan tersebut antara lain: penjadwalan KBM baik di kelas maupun ekstrakurikuler; penyediaan fasilitas penunjang belajar mengajar; penggunaan bahan ajar; penyusunan materi; penawaran program-program sekolah; pemilihan kegiatan ekstrakurikuler; dan sebagainya. Pengaturan tentang berbagai hal struktural tersebut, bisa menjadi sumber keberadaan hidden curriculum yang akan mempengaruhi 


\section{Peran Budaya Sekolah sebagai Hidden Curriculum Pembentuk Karakter Lulusan Lembaga Pendidikan Islam}

persepsi siswa akan sesuatu. Misalnya, jika sekolah menyelenggarakan kegiatan ekstrakurikuler dengan jadwal waktu relatif singkat, dan dengan fasilitas yang minim, peserta didik dapat memiliki persepsi bahwa kegiatan ekstra merupakan kegiatan tidak penting, dan tidak bisa dijadikan hal serius dalam kehidupan mereka kelak. Padahal bisa jadi, kegiatan ekstra menjadi hal yang lebih mereka minati dan akan lebih bermanfaat bagi kehidupan mereka di masa depan. Contoh lain: jika sekolah menjadwalkan pembelajaran Agama secara lebih intensif, dengan jam yang ditambah, kemungkinan siswa akan memiliki persepsi pentingnya pelajaran Agama dalam kehidupan mereka. Dengan demikian, kebijakan-kebijakan yang berkaitan dengan aspek struktural perlu dipertimbangkan betul dampaknya bagi perkembangan pola pikir peserta didik ke depannya.

Kedua, yang tidak kalah penting dari aspek pertama, yang dibahas lebih banyak dalam artikel ini adalah aspek kultural atau budaya. Budaya umumnya didefinisikan sebagai nilai-nilai, asumsi-asumsi, pemahaman, dan cara berfikir yang secara bersama-sama oleh anggota organisasi diakui dan dijalankan. ${ }^{13}$ Secara kongkrit, hal-hal yang termasuk di dalam aspek ini antara lain: nilai, norma dan etos sekolah; penataan dekorasi dan dinding ruangan; peran dan hubungan antara pendidik dan siswa, ritual dan perayaan; asumsi

\footnotetext{
${ }^{13}$ Lihat Mulyadi, Kepemimpinan Kepala Sekolah dalam Mengembangkan Budaya Mutu, (Malang; UIN -MALIKI PRESS, 2010), hal. 93; D.L Goetsch dan D.L Davis. Introduction to Total Quality: Quality Management for Production, Process, and Service. Edisi Terjemahan. oleh Benyamin Molan. Jakarta: PT Prenhalindo, 2002), hlm. 10; Stephen P. Robbins, Organizational Behavior. (New Jersey: Pearson Education International, 2001), hlm. 34.; Zamroni. Dinamika Peningkatan Mutu, (Yogyakarta: Gavin Kalam Utama., 2011), hlm. 297
} 


\section{Binti Nasukah}

dan harapan pendidik terhadap siswa; pola pikir penyelenggara LPI, dan sebagainya.

Budaya yang terbentuk dalam sebuah institusi pendidikan, bisa menjadi sumber pesan dari hidden curiculum, yang bisa lebih ampuh dalam membentuk persepsi dan karakter peserta didik ke depannya. Seperti misalnya, norma-norma yang diajarkan guru secara tidak langung saat mengajar siswa. Jika guru menghukum siswa dengan tindak kekerasan kepada siswa yang melakukan kesalahan, maka itu bisa menjadi pesan bagi siswa bahwa kekerasan itu hal biasa, dan bisa mereka lakukan kepada teman atau siswa lain yang menurut mereka telah melakukan kesalahan. Jika guru menyuruh seluruh anak di kelas untuk diam, dan mendengarkan mereka selama pelajaran, tanpa mengajak siswa berinteraksi, bertanya jawab, maka itu bisa menjadi pesan bagi siswa bahwa mereka lebih diharapkan menjadi siswa yang pendiam dibanding siswa yang aktif. Keberadaan perayaan hari besar Islam, dapat menumbuhkan kecintaan siswa pada agamanya. Dan, masih banyak hal-hal lain yang menjadi bagian dari budaya sebuah sekolah, tanpa disadari diserap oleh siswa dan menjadi bagian dari persepsi mereka akan sesuatu.

Hal yang perlu disadari para pengelola LPI adalah bahwa sebagai sumber keberadaan hidden curriculum, budaya bisa menjadi lawan atau antitesis bagi kurikulum resmi, yang menjadi tujuan atau sasaran dari 


\section{Peran Budaya Sekolah sebagai Hidden Curriculum Pembentuk Karakter}

Lulusan Lembaga Pendidikan Islam

pendidikan di LPI. Sebagai contoh, sementara kurikulum resmi pelajaran sosial biasanya menekankan sistem dan prinsip-prinsip politik demokratis, tetapi guru justru menghendaki adanya pemikiran siswa yang seragam, dengan tidak memberikan siswa kesempatan untuk memiliki pandangan tersendiri akan sesuatu. Bisa jadi kurikulum resmi menghendaki adanya keadilan dan kesetaraan dalam pelayanan, tetapi kecenderungan sekolah untuk lebih menganakemaskan anak pejabat, bisa menjadi sumber pesan bagi siswa bahwa mereka diberikan pelayanan sesuai dengan status sosial mereka, sehingga siswa akan memiliki persepsi bahwa kedudukan dan status itu penting dan segala-galanya. Sekolah menghendaki dalam kurikulum agar siswa menjadi siswa kreatif, dan terampil, tetapi bisa jadi dalam pelaksanaanya, guru lebih suka kegiatan menjelaskan daripada kegiatan memberikan siswa kegiatan belajar yang aktif dan kreatif. Sehingga siswa lebih cenderung suka diam dan pasif. Contoh-contoh sederhana tersebut menunjukkan bahwa di menunjukkan perlunya kehati-hatinya para pengelola LPI untuk mengevaluasi budaya yang saat ini terbentuk di lingkungan mereka.

\section{Peran Penting Budaya Sekolah yang Positif}

Sebagai sumber dari keberadaan hidden curriculum, pembentukan budaya sekolah yang positif (Positive school culture), mutlak diperlukan. Secara empiris, telah banyak bukti yang menunjukkan peran penting budaya positif 


\section{Binti Nasukah}

sebuah institusi pendidikan, baik bagi siswa maupun bagi penyelengara pendidikan (administrator). Frayns et al.14, dalam survey-nya terhadap 860 sekolah di Illinois, menemukan bahwa budaya akademik yang kuat dapat memotivasi siswa. Macneil et al. ${ }^{15}$, yang meneliti 29 sekolah di Texas, mendapati bahwa siswa yang mendapatkan nilai skor lebih tingga dari hasil tes yang standar didapatkan oleh siswa yang berasal dari sekolah yang memiliki lingkungan belajar yang sehat. Cheng ${ }^{16}$ mendapatkan bahwa budaya sekolah yang memiliki ideologi kuat, berbagi partisipasi, kepemimpinan yang demokratis, serta hubungan yang akrab, guru merasa memiliki kepuasan tinggi, sehingga dapat meningkatkan produktivitas mereka. Hasil-hasil empiris ini membuktikan bahwa mustahil menciptakan output lulusan dengan perilaku atau akhlak yang diharapkan dengan menghiraukan keberadaan budaya sekolah.

Berbagai kemungkinan hasil sampingan yang tidak diharapkan dapat terjadi jika sekolah mengabaikan keberadaan peran penting budaya sekolah. Mungkin sekolah tidak menyadari bahwa mereka telah menciptakan budaya bullying melalui perploncoan, mengajarkan kekerasan melalui bagaimana cara mereka menghukum siswa, mengajarkan nepotisme melalui penerimaan siswa baru yang lebih mengedepankan kedekatan hubungan, mengajarkan kolusi

\footnotetext{
${ }^{14}$ Leslie J. Fyans Jr., and Martin L. Maehr. School Culture, Student Ethnicity, and Motivation. Urbana, Illinois: The National Center for School Leadership, 1990. 29 pages.ED327 947.

${ }^{15}$ Angus J. Macneil, Doris L. Prater And Steve Busch, The Effects Of School Culture And Climate On Student Achievement, Nt. J. Leadership In Education, January-March 2009, Vol. 12, No. 1, 73-84

${ }^{16}$ Yin Cheong Cheng, Profiles of Organizational Culture and Effective Schools. School Effectiveness and School Improvement 4, 2 (1993): 85-110.
} 


\section{Peran Budaya Sekolah sebagai Hidden Curriculum Pembentuk Karakter Lulusan Lembaga Pendidikan Islam}

melalui bagaimana mereka membantu siswa menyelesaikan UN demi tercapainya target kelulusan, mengajarkan korupsi dan indisipliner melalui keterlambatan atau ketidakhadiran pengajar dalam perkuliahan, mengajarkan pragmatisme melalui melihat ketebalan makalah dibandingkan isi, dan masih banyak hal lain yang harusnya mengingatkan kepada para pengelola dan pendidik bahwa kesemuanya itu akan berdampak pada ketidaktercapaian output lulusan yang diharapkan. Wren ${ }^{17}$ telah menegaskan bahwa pemahaman yang baik tentang hidden curriculum, akan membantu pendidik dalam mencapai tujuan efektivitas pendidikan.

Dengan demikian, positive school culture harus ditumbuhkan dan ditancapkan di lingkungan LPI. Untuk dapat menumbuhkannya, maka hal penting yang pertama yang harus dilakukan oleh para penyelenggara pendidikan adalah memahami dan mengikuti keberadaan konsep hidden curriculum dalam pemikiran mereka. Artinya, mereka harus menyadari sepenuhnya dalam benak mereka bahwa siswa belajar dari tidak hanya melalui sistem pengorganisasian yang telah dijalankan di sekolah dan materi kurikulum yang mereka ajarkan, tetapi juga lingkungan tempat mereka berinteraksi, bersosialisasi, melalui sikap dan perilaku dari para guru dan admnistrator sekolah, melalui norma-norma dan nilai-nilai yang mereka terima, lihat dan dengarkan, melalui pola pikir para penyelenggara

\footnotetext{
${ }^{17}$ David J. Wren, School Culture: Exploring the hidden curriculum. Adolescence, Fall 1999, 34, 135, pp. 593-596
} 


\section{Binti Nasukah}

pendidikan, melalui visi misi dan core value yang dibangun, melalui kepemimpinan, dan sebagainya, yang kesemuanya itu ada dalam tatanan yang disebut dengan school culture (budaya sekolah). Melalui school culture inilah, hidden curriculum akan selalu ada, muncul setiap hari selama pengoperasian sekolah berjalan.

Setelah memahami keberadaan hidden curriculum melekat pada budaya sekolah, maka selanjutnya para penyelenggara pendidikan harus mengetahui, mengeksplorasi dan memahami aspek-aspek apa saja yang turut berperan dalam membentuk budaya sekolah tersebut. Dengan memahami peran masing-masing aspek-aspek pembentuk budaya ini, maka pendidik dan administrator dapat mengevaluasi berbagai sumber dari hidden curriculum yang selama ini telah tidak sengaja mereka ajarkan, yang ikut serta membentuk karakter siswa. Menurut Philip Brown ${ }^{18}$ terdapat lima aspek yang turut membangun school culture: (1) Persepsi pendidik terhadap peserta didik; (2) kesempatan siswa untuk dapat menjalin hubungan dengan pihak sekolah; (3) Visi, misi dan sasaran sekolah; (4) stabilitas kepemimpinan sekolah; dan (4) Prioritas orang dewasa di sekolah. Kelima aspek ini memiliki peran penting tumbuhnya budaya sekolah yang menjadi hidden curriculum sebuah LPI. Pemahaman kelimanya akan membuka wawasan bagi para

\footnotetext{
${ }^{18}$ Philip Brown. Intertwining School Culture and Hidden Curriculum: A Positive Influence on Young Adolescents. North Carolina Association for Middle Level Education Journal. Fall 2015, Vol. 29, No. 1, hlm 4-8
} 
penyelenggara pendidikan, akan pentingnya kelima aspek tersebut dalam mewujudkan terciptanya generasi insan kamil.

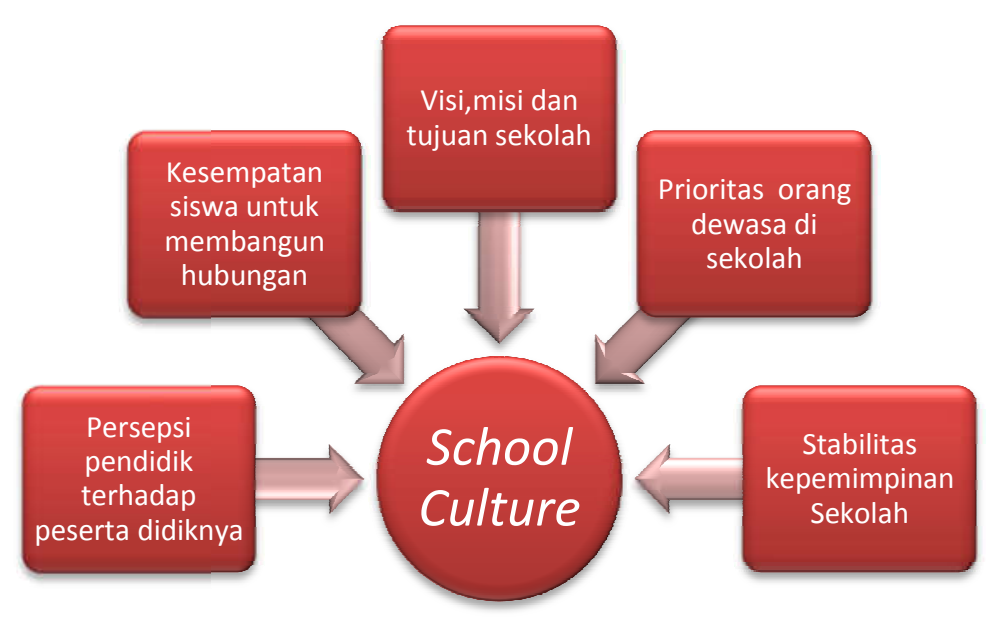

Gambar 1. Aspek-aspek pembangun budaya sekolah

\section{a. Persepsi Pendidik terhadap Peserta Didik}

Pendidik (guru) biasanya memiliki usia yang berbeda dengan anak didiknya. Bisa dikatakan dengan istilah 'beda generasi'. Perbedaan ini tentu membawa pada arah banyaknya perbedaan pemikiran di antara mereka. Guru cenderung ingin dihormati dan murid cenderung ingin dipahami atau dimengerti. Dengan demikian, kesuksesan membentuk budaya sekolah yang positif, akan sangat bergantung pada bagaimana persepsi pendidik terhadap peserta didik mereka. Bagaimanapun, mendidik dan membangun hubungan dengan siswa yang memiliki usia berbeda, bisa jadi merupakan hal yang membikin frustasi. Ada banyak 


\section{Binti Nasukah}

kasus di mana guru mencap seorang siswa sebagai anak nakal, dan sebaliknya siswa merasa bahwa ada guru yang tidak menyukainya. Ini merupakan tantangan bagi pendidik, dan persepsi baik mereka terhadap anak didik, menjadi sangat penting.

Pendidik atau guru memiliki andil besar dalam menciptakan budaya positif disekolah. Jika seluruh pendidik dan bahkan beserta stafnya memiliki persepsi yang baik terhadap peserta didik mereka; mendidik mereka secara ikhlas hanya mengharap ridho Allah, mengajarkan kejujuran, kesantunan, dan kebaikan; melayani dengan prinsip keadilan untuk semua dan tanpa pandang status, mengajarkan profesionalitas, menghormati pendapat yang berbeda, maka tentu ini akan menjadi pengalaman berharga bagi siswa, sehingga akan tertanam pada mereka karakter-karakter kebaikan yang dapat mereka teruskan di mana saja mereka berada. Untuk itu, paradigma bahwa pendidik adalah teladan, apa saja yang mereka perbuat akan menjadi contoh bagi peserta didik, menjadi penting tertanam dalam benak pendidik. Guru adalah ulama, yaitu pewaris para nabi, ${ }^{19}$ yang mengemban amanah membentuk manusia yang berjiwa tauhid, kreatif, beramal shaleh, serta bermoral yang tinggi.

Disisi lain, pendidik atau guru mempengaruhi perkembangan moral siswa tidak hanya sebatas sebagai role model (contoh), tetapi juga yang tidak

\footnotetext{
${ }^{19}$ Ahmad Izzan dan Saehudin, Tafsir Pendidikan: Studi Ayat-Ayat berdimensi Pendidikan, (Banten: PAM Press, 2012), hlm. 163
} 


\section{Peran Budaya Sekolah sebagai Hidden Curriculum Pembentuk Karakter Lulusan Lembaga Pendidikan Islam}

kalah pentingnya adalah sebagai patner interaksi di mana terjalin hubungan antara keduanya setiap harinya, sehingga seorang pendidik dituntut untuk memiliki kemampuan-kemampuan antara lain: kemampuan mereka untuk mengapresiasi pandangan-pandangan siswa yang kadang mungkin berbeda dengan guru; kemampuan dalam menerima dan belajar dari etika yang salah, kemudian menunjukkan idealisme yang baik; kemampuan dalam membantu siswa mengembangkan pemikiran moral tanpa terkesan mendikte, kemampuan guru mengendalikan emosi, kemampuan guru mengajarkan sportivitas dan sebagainya.

Pendidik atau guru harus memahami bahwa dalam hubungan mereka dengan siswa-siswinya, akan secara otomatis membentuk moral siswanya. Guru harus memahami bahwa membentuk akhlak mulia siswa tidaklah mudah hanya sekedar mentransfer pengetahuan saja. Kualitas moral siswa akan terbentuk dari hubungan jangka panjang dengan gurugurunya. Dibutuhkan guru yang adil, murah hati, peduli dan memiliki empati, berbudi pekerti baik, agar dapat secara efektif menanamkan nilainilai kebaikan dalam diri peserta didik. Sifat-sifat tersebut pada dasarnya merupakan sifat yang sangat berkaitan dengan perasaan atau emosi seseorang. Dalam hal ini dibutuhkan guru yang memiliki kematangan emosional yang baik. Guru dianjurkan untuk memiliki kesabaran ekstra 


\section{Binti Nasukah}

dengan tidak melakukan sikap emosional seperti marah dan sinis, karena hasil penelitian Rozin, et.al ${ }^{20}$ menunjukkan bahwa perbuatan-perbuatan emosional tersebut dapat membunuh rasa peduli, tanggungjawab dan moral baik lainnya. Lumpkin ${ }^{21}$ menyebutkan bahwa guru harus memiliki integritas dengan selalu melakukan hal-hal yang benar meskipun tidak dilihat orang lain. Integritas bermakna secara konsisten melakukan hal benar meski tidak mudah dan tidak menguntungkan dan bahkan tidak di lihat orang lain. Sifat-sifat yang menjadi bagian dari integritas tersebut, disebutkan Lumpkin, antara lain: jujur, dapat dipercaya, adil, menghormati orang lain dan tanggung jawab. Guru yang memiliki integritas akan menjaga janjinya, menahan diri dari melakukan kebohongan, curang, dan mencuri karya orang lain. Hal ini penting mengingat siswa seringkali melakukan hal-hal seperti mencontek, meng-copy karya orang lain, dan bertindak tidak sportif demi hasil yang memuaskan.

b. Kesempatan Siswa untuk dapat Menjalin Hubungan dengan Pihak Sekolah

Beberapa kasus menunjukkan bahwa sekolah seringkali lebih suka menjalin hubungan yang sifatnya satu arah. Dalam artian, sedikit atau

\footnotetext{
${ }^{20}$ Rozin, P., et al. (1999). The mapping between three moral emotions (contempt, anger, and disgust) and three $\mathrm{m}$ oral codes (community, autonomy, divinity). Journal of Personality and Social Psychology, 76(4), 574-586.

${ }^{21}$ Angela Lumpkin, Teacher as Role Models Teaching Character and Moral Virtues, JOPERD, Vol. 79, No. 2, February 2008, pp: 45-49
} 


\section{Peran Budaya Sekolah sebagai Hidden Curriculum Pembentuk Karakter Lulusan Lembaga Pendidikan Islam}

bahkan sama sekali tidak memberikan kesempatan kepada siswa, orang tua atau stakeholder lain untuk bisa dengan mudah berkomunikasi dengan mereka. Sekolah akan hanya akan memberikan apa yang mereka ingin berikan, tanpa memberikan kesempatan utamanya kepada siswa untuk memberikan ide atau masukan. Padahal, jika dilihat, ada banyak literatur menunjukkan peran penting siswa bagi kemajuan sebuah lembaga pendidikan. Seorang siswa bisa saja menanyakan adanya ekstrakurikuler yang menjadi minatnya, tetapi tidak disediakan di sekolah. Jika hal ini direspon baik oleh sekolah, maka bukan tidak mungkin sekolah bisa membangun prestasi baru di bidang yang diminati siswa tersebut. Kemudahan siswa untuk dapat terus menjalin komunikasi secara timbal balik, akan sangat penting dalam membangun budaya positif di sekolah. Siswa akan merasa dihargai dan merasa mereka memiliki gairah untuk tetap mau bersekolah. Sebaliknya, jika sekolah lebih cenderung anti saran atau kritik, akan dapat memunculkan budaya stagnasi dalam diri siswa. Siswa tidak akan pernah memperoleh kesempatan mengembangkan dirinya sesuai dengan apa yang mereka inginkan.

LPI perlu mengusahakan terciptanya hubungan timbal balik antara siwa dengan pihak sekolah. Siswa tidak hanya butuh mendengarkan, kadangkala mereka butuh didengarkan. Hubungan timbal balik yang baik antara guru dengan siswa, sekolah dengan orangtua, akan bisa 


\section{Binti Nasukah}

menciptakan keterbukaan yang baik di sekolah. Hal ini menunjukkan bahwa sekolah memberikan penghargaan kepada pihak lain. Menganggap bahwa terdapat hubungan saling membutuhkan dan saling menghargai satu sama lain. Kondisi positif ini jika terus dibangun akan dapat membangun karakter siswa yang saling menghargai dan menghormati satu sama lain.

\section{c. Visi, Misi dan Sasaran Sekolah}

LPI harus mengetahui jawaban atas pertanyaan "untuk apa mereka ada?". Pertanyaan ini akan mengarahkan pada terbentuknya visi, misi dan sasaran sekolah. pengembangan visi, misi dan sasasarn ini merupakan kegiatan filosofis yang membutuhkan waktu tidak sebentar, tetapi harus ditentukan untuk bisa menciptakan core value (nilai-nilai utama) yang akan dijadikan pegangan, pedoman dan panduan bagaimana setiap individu dalam institusi harus berperilaku. Hubungan antara visi, misi, dan core values ini digambarkan Mulyadi22 sebagaimana berikut:

\footnotetext{
${ }^{22}$ Mulyadi, Perumusan Visi, Misi CoreBeliefs dan Core values Organisasi, Manajemen Usahawan Indonesia (No. 01/th XXVII Januari 1998), hlm. 11
} 


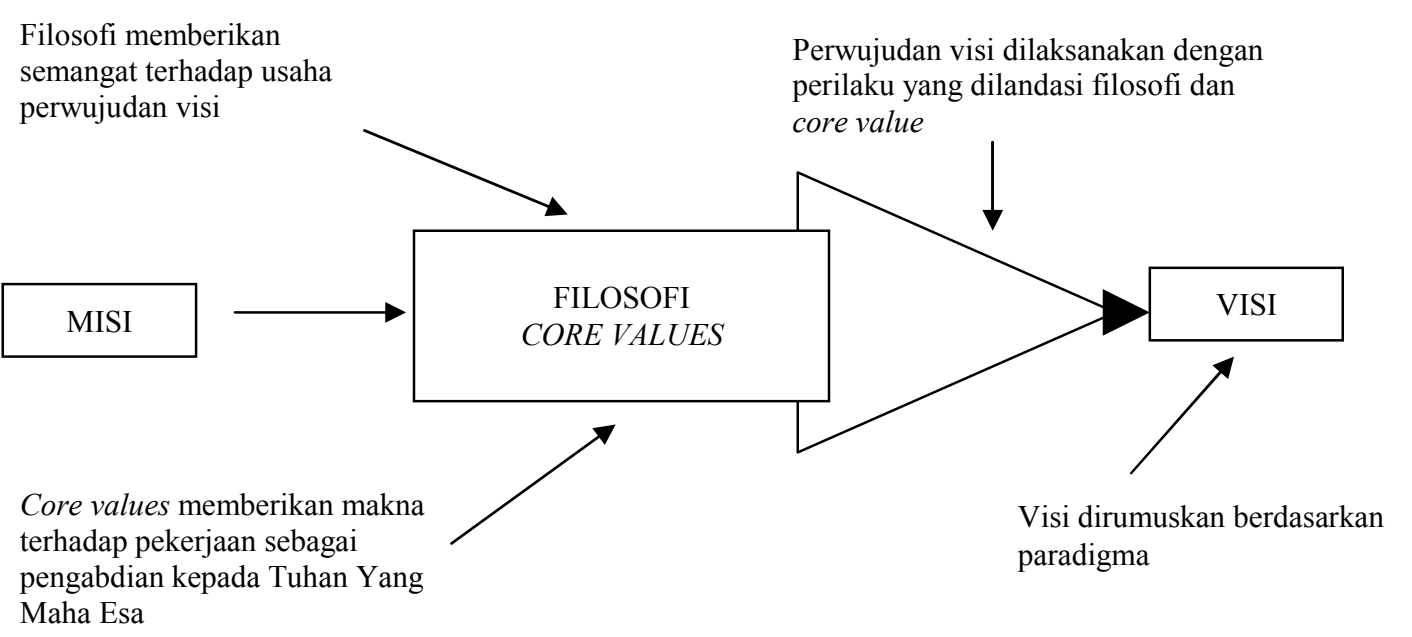

Gambar 2. Hubungan Misi, Visi, dan Core values

Dari gambar tersebut, dapat dipahami bahwa misi yang diemban oleh sebuah institusi kemudian dijabarkan dalam visi yang didukung oleh adanya filosofi atau falsafat dan core values (nilai-nilai moral) yang menjadi pijakan dalam setiap kegiatan dan menjadi kepercayaan bersama untuk dilaksanakan sesuai dengan nilai yang menjadi kesepakatan.

Visi merupakan gambaran tentang masa depan (future) yang realistis dan ingin diwujudkan dalam kurun waktu tertentu (dapat mengisyaratkan adanya misi dan tantangan). ${ }^{23}$ Dalam hal ini visi menjadi representasi masa depan yang diinginkan mengenai sebuah institusi. Ingin menjadi seperti apa institusi, setidaknnya lima tahun atau sepuluh tahun ke depan.

${ }^{23}$ Akdon, Strategic Management For Educational Management, ( Bandung, Alfabeta :2009) hal :94 


\section{Binti Nasukah}

Sedangkan misi merepresentasikan alasan mendasar mengapa sebuah institusi tersebut didirikan. Rumusan misi mencakup pesan-pesan pokok tentang (1) tujuan asal-muasal (original purpose) didirikannya intitusi , (2) nilai-nilai yang dianut dan melandasi pendirian dan operasionalisasi institusi, dan (3) alasan mengapa institusi tersebut harus tetap dipertahankan keberadaannya. ${ }^{24}$ Dengan demikian misi akan berisi pernyataan tentang bagaimana sekolah dapat memberikan layanan terbaik kepada peserta didik dan mencapai visi yang telah dirumuskan. Misi bukan merupakan jabaran dari visi, akan tetapi misi merupakan cara untuk mencapai visi. Merumuskan misi sekolah berarti merumuskan pernyataan tentang bagaimana sekolah akan menyelenggarakan pendidikan dan bagaimana cara sekolah mencapai visi yang telah dicanangkan

Untuk selanjutnya, misi harus dijabarkan dalam Goal/ sasaran atau tujuan strategis institusi atau lembaga pendidikan tersebut. Sasaransasaran tersebut harus terkait dengan usaha mendorong perkembangan semua siswa baik secara intelektual, fisikal, sosial, personal, spiritual, moral, kinestetikal, maupun estetikal. Dengan demikian, tujuan tersebut harus memberikan fokus yang jelas bagi institusi terkait capaian-capaian apa yang harus diraih. Ada target-target yang ingin dicapai dalam rangka mewujudkan visi dan misi.

\footnotetext{
${ }^{24}$ Direktorat Tenaga Kependidikan, Pendidikan Dan Pelatihan Penyusunan Rencana Strategis Dalam Pengembangan Sekolah Dasar, (Direktorat Jenderal Peningkatan Mutu Pendidik Dan Tenaga Kependidikan Departemen Pendidikan Nasional, 2007), hlm. 24
} 


\section{Peran Budaya Sekolah sebagai Hidden Curriculum Pembentuk Karakter} Lulusan Lembaga Pendidikan Islam

Selanjutnya, sasaran-sasaran tersebut harus dibarengi dengan ditetapkannya core values yang merupakan prinsip-prinsip dan standarstandar yang menjadi inti atau pusat dari karakter seseorang, yang karenanya mereka tidak akan tersesat. ${ }^{25}$ Core values ini sifatnya harus stabil dan hanya dapat berubah dalam jangka waktu yang lama, karena nantinya harus dapat membentuk budaya positif, yang mendorong terciptanya manusia-manusia yang berakhlak mulia. Inilah yang menjadi poin penting visi, misi dan sasaran pendidikan. Para pendiri LPI, harus menganalisis secara kritis mengenai core values apa yang akan diinternalisasikan dalam lingkungan institusi. Termasuk juga menentukan alasan rasional penetapan atas nilai-nilai tersebut, agar tidak terkesan menjadi doktrin yang tidak dapat dimengerti secara rasional. Misalnya, dalam penerapan hukuman, bolehkan menggunakan kekerasan fisik; bolehkah memarahi dengan emosi tinggi; haruskah kelas laki-laki dan perempuan di pisah; terbukakah sekolah dengan perkembangan penggunaan ICT, dan masih banyak yang lainnya, yang seyogyanya dapat dievaluasi keberadaannya guna mendukung terciptanya output lulusan yang diharapkan.

\section{d. Stabilitas Kepemimpinan Sekolah}

Kepemimpinan dalam pendidikan merupakan kepemimpinan yang paling spesifik karena kesuksesan mendidik generasi, membina umat, dan

\footnotetext{
${ }^{25}$ David Grusenmeyer, Mission, Vision, Values \& Goals, (Pro-Dairy) https://www.msu.edu/.../estate\%20Goals\%20Mission\%20Values\%20Over...
} 


\section{Binti Nasukah}

berusaha membangkitkannya terkait erat dengan pemenuhan kepemimpinan pendidikan yang benar ${ }^{26}$. Jika merujuk pada definisi, maka kepemimpinan pendidikan didefinisikan sebagai suatu kemampuan dalam proses mempengaruhi, mengkoordinir orang-orang lain yang ada hubungannya dengan ilmu pendidikan dan pelaksanaan pendidikan dan pengajaran, agar kegiatan-kegiatan yang dijalankan dapat berlangsung lebih efisien dan efektif di dalam pencapaian tujuan-tujuan pendidikan dan pengajaran. ${ }^{27}$ Dari definisi tersebut maka poin penting terkait adanya kepemimpinan ini adalah kemampuan seorang pemimpin dalam mengkondisikan para anggota atau bawahannya untuk bersinergi/bekerja sama menuju tujuan organisasi yang diharapkan bersama. Itulah sebabnya kepemimpinan menjadi pusat sumber gerak organisasi.

Kepemimpinan sekolah di LPI akan sangat menentukan seperti apa budaya sekolah yang tercipta. Bagaimana siswa, orang tua, guru, dan karyawan lain memandang sekolah, akan sangat ditentukan oleh kepemimpinan. Jika pemimpin memiliki komunikasi yang baik dengan semua pihak, maka bukan mustahil akan dapat terbentuk ukhuwah Islamiyah. Stabilitas pemimpin dalam memberikan kesempatan siswa untuk bisa berdiskusi secara timbal balik, memberikan lingkungan yang positif untuk guru dapat berkembang sesuai profesionalitas mereka,

\footnotetext{
${ }^{26}$ Jamal Mahdi, Menjadi Pemimpin yang Efektif dan Berpengaruh: Tinjauan Manajemen Kepemimpinan Islam, terj. Anang Syafrudin dan Ahmad Fauzan (Bandung: PT. Syaamil Cipta Media, 2002), hlm. 14

${ }^{27}$ Syaiful Sagala, Manajemen Strategik Dalam Peningkatan Mutu Pendidikan (Bandung:Alfabeta,2007),hlm. 11
} 


\section{Peran Budaya Sekolah sebagai Hidden Curriculum Pembentuk Karakter} Lulusan Lembaga Pendidikan Islam

merespon keinginan para orang tua dengan cara yang baik, akan sangat membantu mengembangkan budaya sekolah yang positif.

Untuk dapat mendorong terciptanya stabilitas budaya sekolah yang positif, Celik ${ }^{28}$, menyebut bahwa dibutuhkan kepemimpinan bermoral (moral leadership) untuk bisa menginternalisasi moral yang baik dalam setiap warga sekolah terutama siswa. Pemimpin yang tidak memiliki moral baik, menurut Celik akan membawa pada suatu kondisi yang disebut polusi moral (moral pollution), yaitu kondisi punahnya nilai-nilai moral atau etika. Disinilah letak pentingya stabilitas kepemimpinan dalam institusi pendidikan

\section{e. Prioritas Orang Dewasa di Sekolah}

Kepala sekolah, guru, dan staf lainnya adalah para orang dewasa yang ada di sekolah. Mereka pada dasarnya memiliki tugas dan keinginan serta prioritas masing-masing dalam benak mereka. Kepala sekolah memiliki prioritas akreditasi; guru memiliki prioritas terselesaikannya materi; staf administrasi memiliki prioritas ketuntasan pembayaran siswa; bagian perpustakaan memiliki prioritas pengembalian buku; dan prioritas lainnya; yang kesemuanya menunjukkan bahwa prioritas mereka adalah terselesaikannya pekerjaan mereka. Seringkali, mereka membuat

\footnotetext{
${ }^{28}$ Vehbi Çelik, Moral leadership in school organization, African Journal of Business Management Vol. 6(28), 18 July, 2012 , pp. 8235-8242,
} 


\section{Binti Nasukah}

keputusan yang berkaitan dengan siswa sesuai dengan pemikiran mereka daripada apa yang menjadi minat siswa. Pada akhirnya, kondisi ini bisa ditangkap oleh siswa sebagai prioritas yang hanya mementingkan kepentingan para orang dewasa tersebut dan membangun persepsi apakah pihak penyelenggara sekolah peduli dengan mereka atau tidak. Jika persepsi ini cenderung negatif, tentu akan sulit bagi sekolah untuk membangun hubungan baik antara pihak sekolah dan siswa, yang pada akhirnya bisa mengarahkan budaya sekolah yang negatif. Akibatnya, bisa jadi siswa akan cenderung enggan untuk secara aktif berpartisipasi dalam kegiatan belajar mengajar di sekolah. Dalam hal ini, sangat penting untuk dapat membangun kepercayaan siswa terhadap sekolah. Prioritas orang dewasa yang akan diimplementasikan kepada siswa harus mampu dijelaskan secara baik oleh pihak sekolah.

Membangun budaya sekolah yang positf, perlu memberikan kesempatan terwujudnya dialog antar pemangku kepentingan, utamanya antara pihak LPI dengan para siswanya. Hal ini akan memberikan kesempatan yang baik bagi sekolah untuk terus memperbaiki kurikulum tersembunyi mereka. Bisa jadi terdapat banyak saran, keluhan, harapan yang dialamatkan kepada sekolah, yang perlu untuk didengar dan lebih baiknya direspon dengan baik. Bisa jadi terdapat berbagai pertanyaan yang diajukan siswa, harapan yang diinginkan siswa atau keluhan-keluhan yang 


\section{Peran Budaya Sekolah sebagai Hidden Curriculum Pembentuk Karakter}

Lulusan Lembaga Pendidikan Islam

disampaikan siswa kepada staf ataupun guru di sekolah. Terbentuknya karakter bangsa seperti: suka membuli, korupsi, kolusi, nepotisme, pragmatisme, dan sebagainya bisa jadi merupakan akibat di mana para orang dewasa di sekolah lebih mementingkan terlaksananya tugas-tugas yang ada di benak mereka, tanpa mengindahkan keberadaan perlunya memperhatikan kebutuhan siswa yang lebih dari sekedar terlaksananya kegiatan belajar mengajar.

\section{KESIMPULAN}

Hidden Curriculum dan budaya sekolah merupakan dua hal yang harus disadari LPI dalam upaya mencetak insan kamil. Dalam melaksanakan kurikulum yang telah direncanakan melalui kegiatan belajar mengajar, siswa juga menyerap hal lain yang tidak disengaja diajarkan oleh pendidik melalui apa yang disebut dengan hidden curriculum. Hidden curriculum adalah merupakan hasil sampingan dari sebuah pendidikan, di mana hasilnya dipelajari tetapi tidak secara tersurat dicantumkan sebagai tujuan. Hasil ini dianggap sebagai pelajaran yang diajarkan informal, dan biasanya tidak sengaja, dalam sistem sekolah, termasuk didalamnya perilaku, perspektif, dan sikap yang diterima siswa selama mereka berinteraksi dan berada di sekolah. Salah satu aspek yang menjadi sumber pesan dari hidden curriculum di sebuah lembaga pendidikan adalah school culture (budaya sekolah). 


\section{Binti Nasukah}

Budaya sekolah menempel sebagai hidden curriculum dari hari ke hari selama dilaksanakannya penyelenggaraan kegiatan belajar mengajar di sekolah.

Budaya sekolah sebagai sumber pesan dari hidden curriculum adalah merupakan suatu pola asumsi-asumsi dasar, nilai-nilai, keyakinan-keyakinan, dan kebiasaan-kebiasaan yang dipegang bersama oleh seluruh warga sekolah. Untuk bisa mewujudkan generasi muda yang memiliki pemikiran, karakter, dan sikap yang positif, LPI harus dapat membangun budaya sekolah yang positif. Terdapat lima aspek pembentuk budaya yang harus diperhatikan LPI dalam membangun budaya sekolah positif, antara lain: (1) persepsi pendidik terhadap anak didiknya, (2) kesempatan siswa untuk membangun hubungan, (3) visi, misi dan tujuan sekolah, (4) stabilitas kepemimpinan (5), prioritas orang dewasa di sekolah. Aspek-aspek ini dapat menjadi evaluasi bagi LPI untuk melihat kembali hidden curriculum, yang telah tidak sengaja mereka jalankan selama proses kegiatan belajar mengajar dilaksanakan. 


\section{Peran Budaya Sekolah sebagai Hidden Curriculum Pembentuk Karakter Lulusan Lembaga Pendidikan Islam}

\section{RUJUKAN}

Akdon. 2009. Strategic Management For Educational Management. Bandung: Alfabeta.

Apple, Michael and Nancy King. 1983. “What Do Schools Teach?" The Hidden Curriculum and Moral Education. Ed. Giroux, Henry and David Purpel. Berkeley, California: McCutchan Publishing Corporation.

Azra, Azyumardi. 2005. Jaringan Ulama Timur Tengah dan Kepulauan Nusantara Abad XVII \& XVIII: Akar Pembaruan Islam Indonesia . Cet. II, Jakarta: Prenada Media.

Brown, Philip. 2015. "Intertwining School Culture and Hidden Curriculum: A Positive Influence on Young Adolescents." North Carolina Association for Middle Level Education Journal. Fall, Vol. 29, No. 1.

Çelik, Vehbi. 2012. "Moral leadership in school organization." African Journal of Business Management Vol. 6 (28), 18 July, pp. 8235-8242,

Cheng, Yin Cheong. 1993. "Profiles of Organizational Culture and Effective Schools." School Effectiveness and School Improvement 4, (2): 85-110.

Cornbleth, Catherine.1984. "Beyond Hidden Curriculum?." Journal of Curriculum Studies. 16, (1), pp: 29-36.

David Grusenmeyer, Mission, Vision, Values \& Goals, (Pro-Dairy). Tersedia online di: https://www.msu.edu/.../estate\% 20Goals\%20Mission\%20Values\%20Over...

Direktorat Tenaga Kependidikan. 2007. Pendidikan Dan Pelatihan Penyusunan Rencana Strategis Dalam Pengembangan Sekolah Dasar. Direktorat Jenderal Peningkatan Mutu Pendidik Dan Tenaga Kependidikan Departemen Pendidikan Nasional.

Fadjar, A. Malik. 1998. Visi Pembaharuan Pendidikan Islam. Jakarta: Lembaga Pengembangan Pendidikan dan Penyusunan Naskah Indonesia.

Fyans, Leslie J. Jr., and Martin L. Maehr. 1990. School Culture, Student Ethnicity, and Motivation. Urbana, Illinois: The National Center for School Leadership.

Goetsch, D.L dan Davis, D.L. 2002. Introduction to Total Quality: Quality Management for Production, Process, and Service. Edisi Terjemahan. oleh Benyamin Molan. Jakarta: PT Prenhalindo.

Hamalik, Oemar 2005, Proses Belajar Mengajar. Jakarta: Bumi Aksara. 


\section{Binti Nasukah}

Horn, Raymond A. Jr. 2003. "Developing a Critical Awareness of the Hidden Curriculum through Media Literacy." The Clearing House, Vol. 76 no. 6 (July/ August), pp. 298-300.

Izzan, Ahmad dan Saehudin. 2012. Tafsir Pendidikan: Studi Ayat-Ayat berdimensi Pendidikan. Banten: PAM Press.

Konieczka, Joanna. 2013. "The Hidden Curriculum: as a socialization of schooling is in process at all times, and serves to transmit messages to students about values, attitudes and principles." Advanced Research in Scientific Areas. December, 2 (6), pp. 250-252

Lumpkin, Angela. 2008. “Teacher as Role Models Teaching Character and Moral Virtues," JOPERD, Vol. 79, No. 2, February, pp: 45-49

Macneil, Angus J.; Doris L. Prater and Steve Busch. 2009. “The Effects Of School Culture And Climate On Student Achievement," Nt. J. Leadership In Education, January-March, Vol. 12, No. 1, pp. 73-84

Mahdi, Jamal. 2002. Menjadi Pemimpin yang Efektif dan Berpengaruh: Tinjauan Manajemen Kepemimpinan Islam, terj. Anang Syafrudin dan Ahmad Fauzan. Bandung: PT. Syaamil Cipta Media.

Martin, Jane.1983. What Should We Do with a Hidden Curriculum When We Find One? The Hidden Curriculum and Moral Education. Ed. Giroux, Henry, dan David Purpel. Berkeley, California: McCutchan Publishing Corporation.

Muhaimin, 2004, Pengembangan Kurikulum Pendidikan Agama Islam, Jakarta: Raja Grafindo.

Mulyadi. 1998. Perumusan Visi, Misi CoreBeliefs dan Core values Organisasi, Manajemen Usahawan Indonesia (No. 01/th XXVII Januari).

Mulyadi. 2010. Kepemimpinan Kepala Sekolah dalam Mengembangkan Budaya Mutu. Malang; UIN -MALIKI PRESS.

Qardlawi, Yusuf. 1980. Pendidikan lslam dan Madrasah Hasan al Banna, terjemah oleh Bustani A. Gani. Jakarta : Bulan Bintang.

Rahim, Husaini. 2001. Arah Baru Pendidikan Islam di Indonesia. Jakarta: PT. Logos Wacana Ilmu.

Robbins, Stephen P. 2001. Organizational Behavior. New Jersey: Pearson Education International. 
Rozin, P., et al. (1999). “The mapping between three moral emotions (contempt, anger , and disgust) and three moral codes (community, autonomy, divinity). Journal of Personility and Social Psychology, 76 (4): 574-586.

Sagala, Syaiful. 2007. Manajemen Strategik Dalam Peningkatan Mutu Pendidikan. Bandung:Alfabeta.

Sumarna, Cecep. 2014. “Alumni Madrasah”, diposting tanggal 7 September 2014, tersedia di http:/ / cecepsumarna.com/alumni-madrasah/

Wren, David J. 1999. "School Culture: Exploring the hidden curriculum." Adolescence, Fall, 34, 135, pp. 593-596

Zamroni. 2011. Dinamika Peningkatan Mutu, Yogyakarta: Gavin Kalam Utama. 


\section{Binti Nasukah}

